\title{
Distribution patterns of decapod crustaceans in polar areas: a result of magnesium regulation?
}

Accepted: 26 March 2001 / Published online: 8 June 2001

(C) Springer-Verlag 2001

\begin{abstract}
Nearly all decapod crustaceans found in Antarctic waters south of the Antarctic Convergence are caridean shrimps (Natantia) while the group of Reptantia is largely absent in this area. Progress in the development of a physiological hypothesis is reported, which explains this distribution pattern based on differences in the regulation of magnesium levels in the haemolymph $\left(\left[\mathrm{Mg}^{2+}\right]_{\mathrm{HL}}\right)$ and on the $\mathrm{Mg}^{2+}$ dependence of threshold temperatures below which cold-induced failure of cardiac and ventilatory performance occurs. Previous studies had shown that an increase in oxygen consumption and activity levels in the cold can be induced by experimental reduction of $\left[\mathrm{Mg}^{2+}\right]_{\mathrm{HL}}$ in different reptant decapod species. In the present study, we tested the potential of these experimental findings for predicting the effect of low $\left[\mathrm{Mg}^{2+}\right]_{\mathrm{HL}}$ in nature, and investigated temperature-induced changes in oxygen consumption in two species with low but different $\left[\mathrm{Mg}^{2+}\right]_{\mathrm{HL}}$ from southern Chile, Halicarcinus planatus and Acanthocyclus albatrossis $\left(\left[\mathrm{Mg}^{2+}\right]_{\mathrm{HL}}=10.7\right.$ and $21.6 \mathrm{mmol} \mathrm{l}^{-1}$, respectively). In accordance with previous findings, low $\left[\mathrm{Mg}^{2+}\right]_{\mathrm{HL}}$ levels were associated with a reduction of thermal sensitivity and a higher metabolic rate in the cold. A model is developed which describes how $\left[\mathrm{Mg}^{2+}\right]_{\mathrm{HL}}$ reduction caused a threshold
\end{abstract}

This paper presents results of the Midterm Symposium of the SCAR programme "Ecology of the Antarctic Sea Ice Zone" (EASIZ). The manuscript was edited by W. Arntz and A. Clarke.

M. Frederich · F.J. Sartoris · Hans-O. Pörtner ( $\square)$ Alfred-Wegener-Institute for Polar and Marine Research, Columbusstrasse, 27568 Bremerhaven,

Germany

E-mail: hpoertner@awi-bremerhaven.de

Tel.: + 49-471-48311307

Fax: +49-471-48311149

Present address: M. Frederich

Brigham and Women's Hospital,

Harvard Medical School, Boston, USA temperature (pejus temperature, $\mathrm{Tp}$ ) to fall, which characterises the onset of cold-induced failure in oxygen supply to tissues. This threshold temperature is interpreted, not only to indicate the limits of cold tolerance, but also of geographical distribution. Tp is shifted towards lower temperatures in Natantia, which are efficient $\left[\mathrm{Mg}^{2+}\right]_{\mathrm{HL}}$ regulators. In contrast, Reptantia, which are poor $\left[\mathrm{Mg}^{2+}\right]_{\mathrm{HL}}$ regulators, appear unable to colonise the permanently cold water of the Antarctic due to insufficient capacity of cardiac performance and, therefore, largely reduced scope for activity at high $\left[\mathrm{Mg}^{2+}\right]_{\mathrm{HL}}$.

\section{Introduction}

Early investigations of the Antarctic shelf fauna seemed to indicate that decapod crustaceans are very rare south of the Antarctic Convergence (Yaldwyn 1965). However, more recent studies, especially in the Weddell Sea, revealed a well-established decapod fauna with eight different species out of seven families (Arntz and Gorny 1991; Arntz et al. 1994), which all belong to the group Caridea (Natantia). The group of Reptantia, which is otherwise very successful in colonising different and even extreme habitats, is almost completely absent in the high Antarctic. Different hypotheses were developed to explain the absence of this whole group of crustaceans, mainly based on larval, ecological or geohistorical patterns. Nevertheless, none of these hypotheses provides a commonly accepted explanation (reviewed by Arntz et al. 1994). This paper reports recent progress in the development of a physiological hypothesis, which explains the absence of Reptantia in the Antarctic based on their inability to regulate magnesium in the haemolymph $\left(\left[\mathrm{Mg}^{2+}\right]_{\mathrm{HL}}\right)$ at low levels, thereby exacerbating problems of oxygen supply to tissues due to limitations of cardiac and ventilatory performance at low temperatures (Frederich et al. 2000a). 


\section{Results and discussion}

Crustacean haemolymph is usually more or less isoionic to seawater except for $\mathrm{Mg}^{2+}$ (Robertson 1960; Mantel and Farmer 1983). Mean $\left[\mathrm{Mg}^{2+}\right]_{\mathrm{HL}}$ of caridean shrimps is found at $5-12 \mathrm{mmol} \mathrm{l}^{-1}$, far below the magnesium concentration of seawater $\left(53 \mathrm{mmol} \mathrm{l}^{-1}\right)$. In contrast, most Reptantia regulate $\left[\mathrm{Mg}^{2+}\right]_{\mathrm{HL}}$ at levels between 30 and $50 \mathrm{mmol} \mathrm{l}^{-1}$, close to seawater concentrations (Walters and Uglow 1981; Tentori and Lockwood 1990). This difference is of special interest since there is a close relationship between $\left[\mathrm{Mg}^{2+}\right]_{\mathrm{HL}}$ and activity. In crustaceans, low $\left[\mathrm{Mg}^{2+}\right]_{\mathrm{HL}}$ values are clearly correlated with higher activity levels, while high $\left[\mathrm{Mg}^{2+}\right]_{\mathrm{HL}}$ values are usually combined with lower activity levels. This holds true for comparisons of activity levels between different species, as well as for comparisons between long-term periods with different levels of activity, like hibernation, within the same species (Robertson 1953, 1960; Kayser 1961; Walters and Uglow 1981; Morritt and Spicer 1993; Spicer et al. 1994). This correlation between $\left[\mathrm{Mg}^{2+}\right]_{\mathrm{HL}}$ and activity has been known for a long time. Pantin (1946) suggested a formula with high $\left[\mathrm{Mg}^{2+}\right]$ to anaesthetise invertebrates, and Robertson (1953) described species such as Maja squinado with their high $\left[\mathrm{Mg}^{2+}\right]_{\mathrm{HL}}$ as "living in a semi-narcotized state".

Elevated activity levels require an adequate oxygen supply to tissues by ventilation and circulation. Several studies have shown that oxygen may become a limiting factor at extreme temperatures and, consequently, both low and high threshold temperatures were defined by the onset of anaerobic metabolism in both invertebrates and fish (Zielinski and Pörtner 1996; Sommer et al. 1997; Pörtner et al. 1998, 2000; Sommer and Pörtner 1999; van Dijk et al. 1999 ; Frederich and Pörtner, 2000). Cold adaptation elicits a shift of both threshold temperatures to lower values to enable the animals to remain fully active at low temperatures.

In previous experimental studies of the effects of temperature and various $\left[\mathrm{Mg}^{2+}\right]_{\mathrm{HL}}$ levels on the physiology of reptant decapod crustaceans, $\left[\mathrm{Mg}^{2+}\right]_{\mathrm{HL}}$ was reduced from 45 to $8 \mathrm{mmol}^{-1}$ by exposing specimens of M. squinado, Hyas araneus and Eurypodius latreillei to seawater with artificially reduced $\left[\mathrm{Mg}^{2+}\right]$ of approximately $6 \mathrm{mmol}^{-1}$ (compared to $53 \mathrm{mmol}^{-1}$ in natural seawater). Animals were subsequently incubated at different temperatures and motor activity, heart rate, oxygen consumption or oxygen tensions in the haemolymph were investigated. As described in detail elsewhere (Frederich et al. 2000a), heart rate of control animals in H. araneus $\left(\left[\mathrm{Mg}^{2+}\right]_{\mathrm{HL}} 46 \mathrm{mmol} \mathrm{l}^{-1}\right)$ decreased linearly between 7.2 and $-1.2^{\circ} \mathrm{C}$ by $72.7 \pm 13.0 \%$. Heart rate in $\left[\mathrm{Mg}^{2+}\right]_{\mathrm{HL}}$-reduced animals $\left(\left[\mathrm{Mg}^{2+}\right]_{\mathrm{HL}} 8 \mathrm{mmol} \mathrm{l}^{-1}\right)$ decreased significantly less - by only $37.2 \pm 17.5 \%$. A different pattern was visible in E. latreillei. Heart rate and oxygen consumption decreased linearly in control animals $\left(\left[\mathrm{Mg}^{2+}\right]_{\mathrm{HL}} 45 \mathrm{mmol} \mathrm{l} \mathrm{l}^{-1}\right)$ and in $\left[\mathrm{Mg}^{2+}\right]_{\mathrm{HL}^{-}}$ reduced animals $\left(\left[\mathrm{Mg}^{2+}\right]_{\mathrm{HL}} 8 \mathrm{mmol} \mathrm{l}^{-1}\right)$. Nevertheless, both parameters were found at significantly elevated levels at all temperatures in $\left[\mathrm{Mg}^{2+}\right]_{\mathrm{HL}}$-reduced animals.

The availability of oxygen to tissues depends upon oxygen uptake by ventilation and on oxygen distribution via haemolymph circulation (cardiac output). These two parameters showed a strong temperature dependence in M. squinado (as described in detail in Frederich et al., 2000b). Cardiac output decreased linearly during progressive cooling between 12 and $8^{\circ} \mathrm{C}$. An overproportional drop led to very low values between 7 and $0^{\circ} \mathrm{C}$. This overproportional drop was also visible in ventilation and occurred between 7 and $6^{\circ} \mathrm{C}$, followed by a transient increase around $4^{\circ} \mathrm{C}$. Arterial $\mathrm{PO}_{2}$ remained almost constant between 12 and $8^{\circ} \mathrm{C}$ and decreased slightly between 8 and $6^{\circ} \mathrm{C}$ in accordance with reduced cardiac and ventilatory activities. The lowest $\mathrm{PO}_{2}$ values were reached below $1^{\circ} \mathrm{C}$ when ventilation had stopped. The overproportional drop in ventilation and circulation could be shifted to lower temperatures when reducing the $\left[\mathrm{Mg}^{2+}\right]_{\mathrm{HL}}$ from $39.9 \pm 4.6$ to $6.1 \pm 0.7 \mathrm{mmol} \mathrm{l}^{-1}$. These previous findings are summarised schematically in Fig. 1, which demonstrates the two patterns of shifting performance of different parameters due to the reduction in $\left[\mathrm{Mg}^{2+}\right]_{\mathrm{HL}}$.

After these initial findings, the question remained open as to whether an experimental reduction of $\left[\mathrm{Mg}^{2+}\right]_{\mathrm{HL}}$ has any relevance for being able to predict the ability of reptant decapods to survive in cold ocean environments. We therefore chose to compare two decapod crustacean species with different, but relatively low, $\left[\mathrm{Mg}^{2+}\right]_{\mathrm{HL}}$, the two South American intertidal crabs Halicarcinus planatus and Acanthocyclus albatrossis. Both species display lower $\left[\mathrm{Mg}^{2+}\right]_{\mathrm{HL}}$ than most other brachyurans: $21.6 \mathrm{mmol}^{-1}$ in A. albatrossis and only $10.7 \mathrm{mmol} \mathrm{l}^{-1}$ in Halicarcinus planatus. Both species live

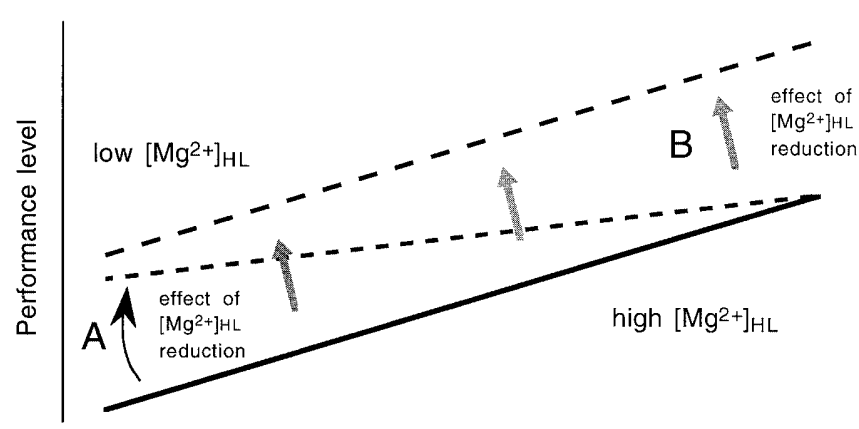

$-\longleftarrow$ Temperature $\longrightarrow+$

Fig. 1 Schematic presentation of a shift in performance parameters crucial for survival (motor activity, heart rate, oxygen consumption) which is induced by lowering $\left[\mathrm{Mg}^{2+}\right]_{\mathrm{HL}}$ experimentally in various reptant decapod species, evidenced by analyses in Hyas araneus, Maja squinado and Eurypodius latreillei. Lowering $\left[\mathrm{Mg}^{2+}\right]_{\mathrm{HL}}$ in E. latreillei resulted in a parallel upward shift $(B)$ while in other investigated species the effect of reduced $\left[\mathrm{Mg}^{2+}\right]_{\mathrm{HL}}$ was visible only at lower temperatures $(A)$. The reason for this difference remains unclear (based on data by Frederich et al. 2000, 2000a) 
in the same environment and inhabit a comparable ecological niche. The reasons for the different capacities of $\left[\mathrm{Mg}^{2+}\right]_{\mathrm{HL}}$ regulation remain obscure since no data are available on the autecology of the two species. In accordance with findings obtained in $M$. squinado at experimentally reduced $\left[\mathrm{Mg}^{2+}\right]_{\mathrm{HL}}$, thermal sensitivity of oxygen consumption in the cold differed between the two species, reflected by different $Q_{10}$ values (Fig. 2). In A. albatrossis, the species with higher $\left[\mathrm{Mg}^{2+}\right]_{\mathrm{HL}}$, oxygen consumption decreased, with a $Q_{10}$ of 6.8 between 8.8 and $-1{ }^{\circ} \mathrm{C}$, while the $Q_{10}$ of 1.3 in Halicarcinus planatus was significantly lower in the same temperature range $(n=5$ per species and group, ANCOVA, $P<0.05)$. In support of the patterns depicted in Fig. 1, oxygen consumption of the species with the lower $\left[\mathrm{Mg}^{2+}\right]_{\mathrm{HL}}$, Halicarcinus planatus, was threefold higher at subzero temperatures than in A. albatrossis.

As summarised in Fig. 1, an elevation of activity can be elicited by a reduction of $\left[\mathrm{Mg}^{2+}\right]_{\mathrm{HL}}$ especially at cold temperatures. Owing to the reduction of thermal sensitivity, $\left[\mathrm{Mg}^{2+}\right]_{\mathrm{HL}}$-reduced crabs displayed elevated heart rates and oxygen consumption values and reacted faster to experimental stimulation, regardless of whether $\left[\mathrm{Mg}^{2+}\right]_{\mathrm{HL}}$ was reduced experimentally or in nature (Fig. 2). Animals were able to survive experimental reductions of $\left[\mathrm{Mg}^{2+}\right]_{\mathrm{HL}}$ for several months, which indicates that elevated $\left[\mathrm{Mg}^{2+}\right]_{\mathrm{HL}}$ levels are not essential for survival, at least under laboratory conditions.

The first report of an effect of experimental $\left[\mathrm{Mg}^{2+}\right]_{\mathrm{HL}}$ reduction on crustaceans is given by Holliday (1980), who described Cancer magister held in $\mathrm{Mg}^{2+}$-free seawater as being "easily excited and aggressive". This corresponds to the results reported in this paper. Elevated excitability and activity might be explained by the inhibitory effect of $\mathrm{Mg}^{2+}$ on synaptic transmitter release at the nerve-muscular junction, and by the competitive

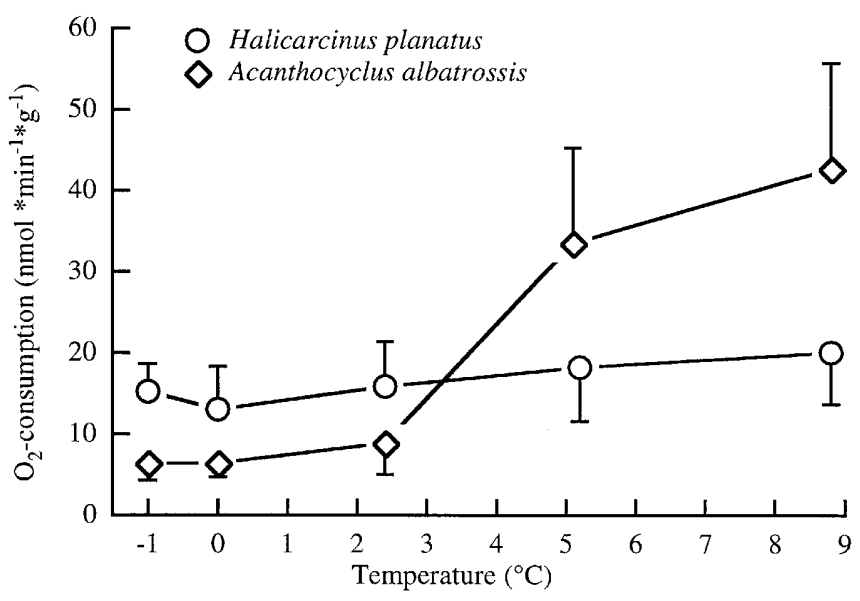

Fig. 2 Oxygen consumption of Halicarcinus planatus and Acanthocyclus albatrossis at different temperatures. Thermal sensitivity was found to be significantly lower in $H$. planatus at $\left[\mathrm{Mg}^{2+}\right]_{\mathrm{HL}}=10.7 \mathrm{mmol} \mathrm{l}^{-1}$ compared to $A$. albatrossis at $\left[\mathrm{Mg}^{2+}\right]_{\mathrm{HL}}=21.6 \mathrm{mmol} \mathrm{l}^{-1}(n=5$ per species and group, ANCOVA, $P<0.05$ ) inhibition of calcium binding (Katz 1936; Del Castillo and Katz 1954; Wernig 1972; Dudel et al. 1982; Howarth and Levi 1998). In accordance with the findings already outlined, elevated levels of $\mathrm{Mg}^{2+}$ seem to act more as a relaxant than as an anaesthetic (Sartoris and Pörtner 1997; Frederich et al. 2000a).

The question of why Reptantia regulate $\left[\mathrm{Mg}^{2+}\right]_{\mathrm{HL}}$ to higher levels compared to Natantia is still open. Few studies indicate that there might be differences in the mechanisms of $\left[\mathrm{Mg}^{2+}\right]_{\mathrm{HL}}$ regulation between Caridea and Brachyura (Holliday 1980; Franklin et al. 1987) but further investigations are necessary to elucidate the details.

The anaesthetising effect of $\mathrm{Mg}^{2+}$ in the cold becomes important in the context of the concept that oxygen is an important factor for defining threshold values at extreme temperatures. At both low and high critical temperatures, animal metabolism switches from aerobiosis to anaerobiosis, and anaerobic endproducts accumulate (reviewed by Pörtner et al. 1998, 2000). In these studies the ambient oxygen did not become limiting, but oxygen supply to tissues did. Therefore, ventilatory and cardiac performance may play an important role in defining thermal tolerance. As shown previously, arterial haemolymph $\mathrm{PO}_{2}$, which represents the pressure head for oxygen diffusion into tissues, is correlated with heart and ventilation rates (Frederich and Pörtner, 2000). The oxygen-binding properties of haemocyanin may change with temperature also; however, since the haemocyanin acts as an oxygen buffer to support maintenance of body fluid $\mathrm{PO}_{2}$, analysis of $\mathrm{PO}_{2}$ gives the most relevant information on the quality of tissue oxygenation.

The findings of decreasing levels of haemolymph $\mathrm{PO}_{2}$ and thus progressive oxygen limitation towards high and low temperature extremes led us (Frederich and Pörtner, 2000) to develop a model in accordance with the "law of tolerance" (Shelford 1913, 1931, Fig. 3). The limiting parameter, arterial $\mathrm{PO}_{2}$, and the progressive failure of cardiac and ventilatory performance towards extreme temperatures characterise various sections of the tolerance range (Fig. 3A). Within the optimum range, oxygen availability and, in consequence, scope for aerobic activity is maximal. The onset of a decrease in arterial haemolymph $\mathrm{PO}_{2}$ at pejus temperatures (Tp; Frederich and Pörtner, 2000; pejus = getting worse) reflects reduced aerobic scope for activity and is accompanied by progressively insufficient cardiac and ventilatory performance. Transitions from pejus to pessimum ranges at critical temperatures (Tc, Pörtner et al. 1998, 2000) are characterised by the onset of anaerobic metabolism and, in consequence, the accumulation of anaerobic endproducts. Within pessimum ranges, survival becomes a question of time due to insufficient oxygen availability. The upper and lower Tc encompass the range of physiological tolerance.

For M. squinado, upper and lower Tp values agree well with the annual minimum and maximum mean temperatures of the environment in the investigated 


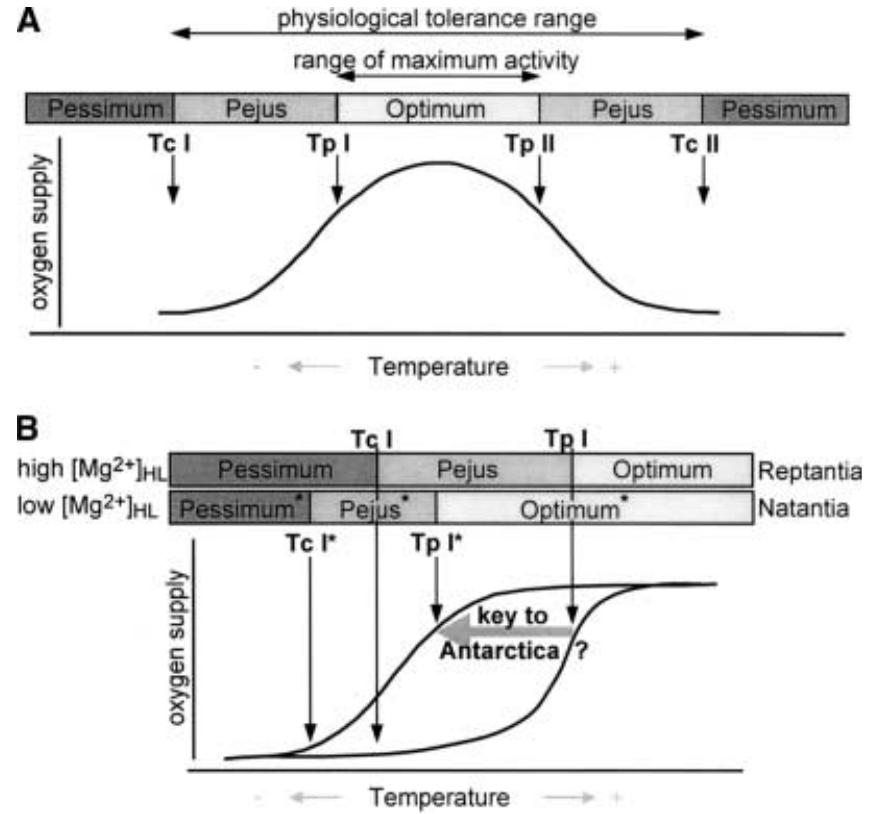

Fig. 3A, B Diagram of physiological threshold temperatures inserted into the law of tolerance. A Pejus temperatures $(T p)$ and critical temperatures $(T c)$ are set by the availability of oxygen to tissues and, therefore, depend on ventilatory and circulatory performance (modified after Frederich and Pörtner, 2000). B The higher efficiency of $\left[\mathrm{Mg}^{2+}\right]_{\mathrm{HL}}$ regulation in Natantia shifts both pejus and critical threshold values to lower temperatures compared to Reptantia with less effective $\left[\mathrm{Mg}^{2+}\right]_{\mathrm{HL}}$ regulation. This shift is most likely a crucial preadaptation for surviving colder temperatures and, therefore, the physiological key for the colonisation of Antarctic shelves by crustaceans

population (Dauvin et al. 1991; Sournia and Birrien 1995) and, therefore, it can be inferred that the Tp values may limit the ecological tolerance range. In this ecological tolerance range, full scope for activity is available to the animals. In consequence, cold adaptation requires an adaptational shift of both $\mathrm{Tp}$ and $\mathrm{Tc}$ values towards lower temperatures to maintain sufficient aerobic activity. This likely involves an adjustment of mitochondrial density and capacity (Pörtner et al. 1998, 2000). As a further step forward in the development of the model depicted in Fig. 3A, it appears that high $\left[\mathrm{Mg}^{2+}\right]_{\mathrm{HL}}$ prevents the shift of $\mathrm{Tp}$ and $\mathrm{Tc}$ to subzero temperatures and thereby limits the capacity of cold adaptation (Fig. 3B).

In summary, the present study shows that slowmoving and sluggish species of Reptantia can be triggered to become more active by decreasing $\left[\mathrm{Mg}^{2+}\right]_{\mathrm{HL}}$ to levels comparable to those found in caridean shrimps. Survival in the natural environment requires sufficient aerobic scope for escape, predation or reproduction. While cold temperatures minimise activity, low $\left[\mathrm{Mg}^{2+}\right]_{\mathrm{HL}}$ levels shift the pejus temperature and, accordingly, the optimum range towards lower values (Fig. 3B). A concomitant shift of the critical temperature is likely. Small differences in cold tolerance by just 1 or $2^{\circ} \mathrm{C}$ result (Fig. 3) and lead to an exclusion of Reptantia from areas with extremely low temperatures in both the Arctic and the Antarctic, where they are only found at temperatures close to $0^{\circ} \mathrm{C}$ and above (Frederich et al. 2000).

It appears likely that efficient $\left[\mathrm{Mg}^{2+}\right]_{\mathrm{HL}}$ regulation in Natantia was an important preadaptation for surviving the cooling of Antarctica during the Tertiary (Clarke and Crame 1989; Clarke 1990) or allowed successful recolonisation after glaciation cycles (Brey et al. 1996). In contrast, Reptantia with less efficient $\left[\mathrm{Mg}^{2+}\right]_{\mathrm{HL}}$ regulation are narcotised by the combination of low temperatures and high $\left[\mathrm{Mg}^{2+}\right]_{\mathrm{HL}}$ and, in consequence, may have been unable to remain in the Antarctic or to recolonise the shelves after glaciation. Nonetheless, the ability to maintain sufficient levels of motor activity in the cold is obviously only one precondition for survival in the Antarctic environment, which needs to be complemented by adequate lifestyle adaptations.

Acknowledgements Financial support for this work was provided to $M$. Frederich by a travel grant for his stay in Chile from the DAAD (D/97/10464).

\section{References}

Arntz WE, Gorny M (1991) Shrimp (Decapoda, Natantia) occurrence and distribution in the eastern Weddell Sea, Antarctica. Polar Biol 11:169-177

Arntz WE, Brey T, Gallardo VA (1994) Antarctic zoobenthos. Oceanogr Mar Biol Annu Rev 32:241-304

Brey T, Dahm C, Gorny M, Klages M, Stiller M, Arntz WE (1996) Do Antarctic benthic invertebrates show an extended level of eurybathy? Antarct Sci 8:3-6

Clarke A (1990) Temperature and evolution: Southern Ocean cooling and the Antarctic marine fauna. In: Kerry KR, Hempel $\mathrm{G}$ (eds) Ecological change and conservation. Springer, Berlin Heidelberg New York, pp 9-22

Clarke A, Crame JA (1989) The origin of the Southern Ocean marine fauna. In: Crame JA (ed) Origins and evolution of the Antarctic biota. Geol Soc Spec Publ no. 47:253-268

Dauvin JC, Joncourt M, Birrien JL (1991) Température et salinité de leau de mer au large de Roscoff de 1988 à 1990. Cah Biol Mar 32:545-550

Del Castillo J, Katz B (1954) Quantal components of the endplate potential. J Physiol 124:560-573

Dijk PLM van, Tesch C, Hardewig I, Pörtner HO (1999) Physiological disturbances at critically high temperatures. A comparison between stenothermal Antarctic, and eurythermal temperate eelpouts (Zoarcidae). J Exp Biol 202:3611-3621

Dudel J, Parnas I, Parnas H (1982) Neurotransmitter release and its facilitation in crayfish. III. Amplitude of facilitation and inhibition of entry of calcium into the terminal by magnesium. Pflügers Arch 393:237-242

Franklin SE, Teinsongrusme B, Lockwood APM (1987) Inhibition of magnesium secretion in the prawn Palaemon serratus by ethacrynic acid and by ligature of the eyestalks. In: SchmidtNielsen K, Bolis L, Maddrell SHP (eds) Comparative physiology, water, ions and fluid mechanics. Cambridge University Press, Cambridge, pp 173-193

Frederich M, Pörtner HO (2000) Oxygen limitation of thermal tolerance defined by cardiac and ventilatory performance in the spider crab, Maja squinado (Decapoda). Am J Physiol 279:R1531-R1538

Frederich M, Sartoris FJ, Arntz WE, Pörtner HO (2000a) Haemolymph $\mathrm{Mg}^{2+}$ regulation in decapod crustaceans: physiological correlates and ecological consequences in polar areas. J Exp Biol 203:1383-1393 
Frederich M, DeWachter B, Sartoris FJ, Pörtner HO (2000b) Cold tolerance and the regulation of cardiac performance and hemolymph distribution in Maja squinado (Crustacea: Decapoda). Physiol Zool 73:406-415

Holliday CW (1980) Magnesium transport by the urinary bladder of the crab, Cancer magister. J Exp Biol 85:187-201

Howarth FC, Levi AJ (1998) Internal free magnesium modulates the voltage dependence of contraction and $\mathrm{Ca}$ transient in rabbit ventricular myocytes. Pflügers Arch 435:687-698

Katz B (1936) Neuro-muscular transmission in crabs. J Physiol 87:199-221

Kayser C (1961) The physiology of natural hibernation. Pergamon Press, Oxford

Mantel LH, Farmer LL (1983) Osmotic and ionic regulation. In: Mantel LH (ed) The biology of Crustacea, vol 5. Academic Press, New York, pp 53-161

Morritt D, Spicer JI (1993) A brief re-examination of the function and regulation of extracellular magnesium and its relationship to activity in crustacean arthropods. Comp Biochem Physiol 106A:19-23

Pantin CFA (1946) Notes on microscopical techniques for zoologists. Cambridge University Press, Cambridge

Pörtner HO, Hardewig I, Sartoris FJ, van Dijk PLM (1998) Acidbase balance, ion regulation and energetics in the cold. In: Pörtner HO, Playle R (eds) Cold ocean physiology. Cambridge University Press, Cambridge, pp 88-120

Pörtner HO, van Dijk PLM, Hardewig I, Sommer A (2000) Levels of metabolic cold adaptation: tradeoffs in eurythermal and stenothermal ectotherms. In: Davison W, Howard Williams C (eds) Antarctic ecosystems: models for wider ecological understanding. Caxton Press, Christchurch

Robertson JD (1953) Further studies on ionic regulation in marine invertebrates. J Exp Biol 30:279-296

Robertson JD (1960) Osmotic and ionic regulation. In: Waterman TH (ed) The physiology of Crustacea, vol I. Academic Press, New York, pp 317-339
Sartoris FJ, Pörtner HO (1997) Elevated haemolymph magnesium protects intracellular $\mathrm{pH}$ and ATP levels during environmental stress in the common shrimp Crangon crangon. J Exp Biol 200:785-792

Shelford VE (1913) Animal communities in temperate America. University of Chicago Press, Chicago

Shelford VE (1931) Some concepts of bioecology. Ecology 12:455-467

Sommer A, Pörtner HO (1999) Exposure of Arenicola marina (L.) to extreme temperatures: adaptive flexibility of a boreal and a subpolar population. Mar Ecol Prog Ser 181:215-226

Sommer A, Klein B, Pörtner HO (1997) Temperature induced anaerobiosis in two populations of the polychaete worm Arenicola marina (L.). J Comp Physiol 167B:25-35

Sournia A, Birrien JL (1995) La série océanographique côtière de Roscoff (Manche occidentale) de 1985 à 1992. Cah Biol Mar $36: 1-8$

Spicer JI, Morritt D, Taylor AC (1994) Effect of low temperature on oxygen uptake and haemolymph ions in the sandhopper Talitrus saltator (Crustacea: Amphipoda). J Mar Biol Assoc UK 74:313-321

Tentori E, Lockwood APM (1990) Haemolymph magnesium levels in some oceanic Crustacea. Comp Biochem Physiol 95A:545-548

Walters NJ, Uglow RF (1981) Haemolymph magnesium and relative heart activity of some species of marine decapod crustaceans. J Exp Mar Biol Ecol 55:255-256

Wernig A (1972) The effects of calcium and magnesium on statistical release parameters at the crayfish neuromuscular junction. J Physiol 226:761-768

Yaldwyn JC (1965) Antarctic and subantarctic decapod Crustacea. In: Mieghem J van, Oye P van (eds) Biogeography and ecology in Antarctica. The Hague, pp 323-332

Zielinski S, Pörtner HO (1996) Energy metabolism and ATP freeenergy change of the intertidal worm Sipunculus nudus below a critical temperature. J Comp Physiol 166B:492-500 